\author{
Contents list available at Multidisciplinary Journal website \\ Multidisciplinary Journal \\ Journal homepage: https://jurnal.unej.ac.id/index.php/multijournal
}

\title{
Surveilans Penyalahgunaan Bahan Kimia Sintetis Deksametason Pada Jamu Pegal Linu Menggunakan Metode Near Infra Red dan Kemometrik
}

\author{
Surveillance of Chemical Abuse of Dexamethasone Medicines in Sciatica Herbs Using \\ Near Infra Red and Chemometric Methods
}

\author{
Khrisna Agung Cendekiawan ${ }^{1)}$ Sugeng Winarso ${ }^{2)}$ Ancah Caesarina Novi Marchianti ${ }^{3)}$ \\ ${ }^{1)}$ Student in the Faculty of Public Health, Graduate University of Jember \\ ${ }^{2)}$ Lecturer in the Faculty of Public Health, University of Jember \\ ${ }^{3}$ Lecturer in the Faculty of Medicine, University of Jember \\ e-mail:khrisna91agung@gmail.com
}

\begin{abstract}
Law Number 36 of 2009 regarding Health states that the community is given the widest opportunity to process, produce, distribute, develop, improve, and use traditional medicines that can be justified for their benefits and safety. The presence of medicinal chemicals added to traditional medicines (herbs) is not appropriate to the therapeutic dose, resulting in overdosing and causing side effects that can be harmful to the health of the consumers. One of the analytical methods to detect the presence of medicinal chemicals, especially dexamethasone, is the Near Infra Red and Chemometrics method. The research design used in this study was descriptive non-analytic. The population in this study is 28 herbal medicine shop that sells herbal sore-aches traditional medicines (jamu pegal linu) in Jember Regency using the Total Sampling technique. This study is using univariate analysis of frequency distribution. This research shows that there was no chemical content of dexametasone found in all herbal medicine samples in the analysis using the Near Infra Red method while in the Chemometric testing, it was found that one of the herbal samples (code J-C) contained $2 \%$ of dexamethasone. It is imperative to Socialize to the community the impact of using herbal medicine containing medicinal chemicals, and it also needs to be analyzed using the most sensitive methods.
\end{abstract}

Keyword: Chemical Abuse, Dexamethasone, Sciatica Herbs, Near Infra Red, Chemometric Methods

ABSTRACT. Undang-undang Nomor 36 Tahun 2009 tentang Kesehatan menyebutkan masyarakat diberikan kesempatan untuk mengolah, memproduksi, mengedarkan, mengembangkan, meningkatkan, dan menggunakan obat tradisional yang dapat dipertanggungjawabkan manfaat dan keamanannya. Adanya temuan bahan kimia sintetis yang ditambahkan pada obat tradisional tidak sesuai dengan dosis terapetik sehingga mengakibatkan over dosis dan menimbulkan efek samping yang dapat membahayakan bagi kesehatan konsumen. Salah satu metode analisis untuk mendeteksi adanya kandungan bahan kimia obat khususnya deksametason diantaranya menggunakan metode Near Infra Red Dan Kemometrik. Metode ini menyempurnakan metode sebelumnya yang memiliki kekurangan, antara lain biaya analisis yang mahal dan penelitian yang membutuhkan waktu lama. Desain penelitian yang digunakan dalam penelitian ini adalah deskriptif non analitik dengan teknik pengambilan sampel menggunakan teknik Total Sampling. Analisis yang digunakan pada penelitian ini adalah analisis univariat distribusi frekuensi, dimana hasil analisis ini divalidasi menggunakan perbandingan hasil spektra secara kualitatif dan penentuan kandungan kadar secara kuantitatif. Penelitian ini menunjukkan pada analisis menggunakan metode Near Infra Red pada seluruh sampel jamu tidak ditemukan adanya kandungan bahan kimia obat deksametasone dalam sediaan jamu sedangkan pengujian Kemometrik ditemukan adanya satu sampel jamu (kode J-C) mengandung bahan kimia obat deksametason sebesar 2\%. Diperlukan sosialisasi kepada masyarakat dampak penggunaan jamu yang mengandung bahan kimia obat, serta perlu dianalisis menggunakan metode yang paling sensitif.

Kata Kunci: Bahan Kimia Obat, Deksametasone, Jamu, Pegal Linu, Near Infrared, Kemometrik 


\section{PENDAHULUAN}

Pada masa sekarang konsumsi jamu tradisional sedang mengalami peningkatan. Berdasarkan rekapitulasi laporan dari Kementerian Perdagangan pada yang dilakukan pada akhir tahun 2014, telah terjadi peningkatan perdagangan jamu tradisional di dalam negeri sebesar $6,2 \%$ dan $2,1 \%$ ke luar negeri selama 2010 sampai 2014. Hal ini menunjukkan bahwa penggunaan jamu tradisional sedang meningkat di masyarakat.

Disebutkan dalam undang-undang Nomor 36 Tahun 2009 tentang Kesehatan bahwa masyarakat diberikan kesempatan yang seluas-luasnya untuk mengolah, mengembangkan, memproduksi, meningkatkan mengedarkan, dan menggunakan obat tradisional yang dapat dipertanggungjawabkan manfaat dan keamanannya serta memperhatikan efikasi dan efek sampingnya.

Kebanyakan masyarakat Indonesia beranggapan bahwa jamu atau obat tradisional mempunyai kedudukan yang spesial dalam tatanan pengobatan karena jamu merupakan warisan budaya bangsa di bidang kesehatan yang sudah sangat terkenal khasiatnya dan terjamin dapat memberikan kesembuhan serta memelihara kesehatan tubuh. Maka dari itu, secara turun temurun jamu sering digunakan oleh penduduk Indonesia.

Badan Pengawasan Obat dan Makanan selaku badan pengawas tertinggi dalam hal pengawasan obat dan makanan, senantiasa melakukan pengawasan obat tradisional secara berkelanjutan, termasuk terhadap kemungkinan dicampurnya jamu dengan bahan kimia sintetis. Bahan kimia sintetis yang ditambahkan pada obat tradisional (jamu) ini tidak sesuai dengan dosis terapetik dalam literatur, sehingga apabila jamu yang memiliki kandungan bahan kimia sintetis dikonsumsi secara terus menerus dapat mengakibatkan over dosis dan menimbulkan efek samping yang dapat membahayakan bagi kesehatan konsumen.

Hal tersebut sejalan dengan ketentuan dalam Permenkes RI Nomor 007 Tahun 2012 obat tradisional tidak boleh mengandung bahan kimia obat atau hasil isolasi yang berkhasiat obat sehingga sangat diperlukan melakukan metode analisis untuk menditeksi ada atau tidaknya penambahan bahan kimia obat dalam jamu.

Badan Pengawasan Obat dan Makanan rutin dalam menerbitkan peringatan/public warning dengan tujuan agar masyarakat tidak mengonsumsi jamu yang memiliki kandungan bahan kimia sintetis secara berlebihan karena efek samping yang ditimbulkan dapat membahayakan kesehatan. Pada tahun 2013, BPOM telah menemukan 49 merek obat tradisional yang mengandung bahan kimia obat (BKO) dari seluruh Indonesia. ${ }^{2}$ BKO yang paling sering banyak digunakan adalah parasetamol, fenilbutason, dan deksametason. Pada hasil temuan BPOM tersebut, deksametason pada jamu pegal linu berjumlah 7 kasus. Penambahan deksametason pada jamu pegal linu dapat menimbulkan efek samping berupa terjadinya osteoporosis, moon face, glaukoma, dan retensi cairan tubuh, sehingga perlu dilakukan pengawasan terhadap peredaran jamu pegal linu yang mengandung deksametason.
Metode analisis yang pernah digunakan untuk mendeteksi adanya kandungan bahan kimia obat khususnya deksametason antaralain High Performance Liquid Chromatography (HPLC), Spectrofotometry UVVis dan Thin Layer Chromatography (TLC). Ketiga metode ini dapat menunjukkan hasil untuk penelitian, namun ada beberapa kekurangan, yaitu membutuhkan biaya yang tinggi, pelaksanaan instrumentasi tidak simpel dan membutuhkan keahlian khusus. Sehingga berangkat dari kekurangan ini peneliti menggunakan metode Near Infra Red Dan Kemometri untuk mendeteksi kandungan Deksametason pada sampel jamu pegal linu.

Metode analisis untuk mendeteksi adanya kandungan bahan kimia obat khususnya deksametason diantaranya menggunakan metode Near Infra Red Dan Kemometrik. Keunggulan dari metode ini adalah gelombang Infra Merah pada range dekat utamanya dalam penelitian bahan makanan yaitu gabungan antara kecepatan analisa, tingkat ketepatan, dan kemudahan dari percobaan yang dilakukan.

Untuk mempermudah dalam mendapatkan informasi dan referensi yang diinginkan dari spektrum near infra red, saat ini banyak ditentukan oleh kualitas spektrum yang dihasilkan oleh instrumen dan metode kalibrasikuantitasi yang digunakan untuk menganalisa spektrum. Terdapat beberapa metode yang dapat digunakan salah satunya adalah metode kemometrik multivariat seperti analisis komponen utama dan kuadrat terkecil parsial.

Teknologi spektroskopi near infrared (NIR) merupakan salah satu teknologi yang dapat menggantikan metode konvensional yang sudah lebih dulu digunakan dan telah sukses diaplikasikan pada produk pertanian, farmasi, petrokimia dan lingkungan. Teknologi infra merah dekat (near infrared) telah mengalami perkembangan sebagai salah satu metode yang non destruktif yang dapat menganalisis suatu sampel atau senyawa dengan kecepatan tinggi dan tidak menimbulkan cemaran. Penggunaan preparat yang sederhana sehingga memudahkan analis dalam pelaksanaan instrumentasi dan tidak memerlukan bahan kimia. Spektroskopi NIR menggunakan gelombang elektromagnetik dengan panjang gelombang $780 \mathrm{~nm}$ $2500 \mathrm{~nm}$ atau bilangan gelombang $12.800 \mathrm{~cm}-1$ hingga $4000 \mathrm{~cm}-1 .^{3}$

Pengolahan data spektrum infra merah dekat dilakukan menggunakan metode statistik multivariat. Manfaat dari metode statistik multivariat tersebut adalah kemampuannya menggunakan informasi spektrum untuk analisa kualitatif dan kuantitatif dalam instrumentasi. Teknik kemometrik seperti analisis multivariat dapat digunakan untuk memudahkan analisa data. ${ }^{4}$ Keuntungan dari penggunaan teknik kemometrik untuk interpretasi spektrum IR adalah kemampuannya dalam menghubungkan profil spektrum dengan informasi yang terdapat pada sampel.

\section{Metode penelitian}

Metode penelitian yang digunakan dalam penelitian ini adalah analisa penelitian deskriptif, dimana akan 
dilakukan penelitian deskripsi dibandingkan dengan penelitian analitis. Lokasi dilakukan penelitian ini berada di toko jamu yang berada diwilayah kerja Dinas Kesehatan Kabupaten Jember pada bulan April sampai Juni 2019. Sedangkan untuk uji sampel jamu di uji kandungan bahan kimia di Laboratorium Fakultas Farmasi Universitas Jember. Teknik yang dilakukan dalam proses pengambilan sampel dalam penelitian ini menggunakan teknik pendekatan Total Sampling pada sampel jamu dari 28 toko jamu di Kabupaten Jember

Tabel 1. Perhitungan simulasi Training Set

Langkah awal dari penelitian ini adalah dibuat simulasi training set dengan perhitungan presentase dan pengkategorian berdasarkan kandungan deksametason. Apabila tidak terdapat kandungan deksametason (0\%) dikategorikan murni. Sedangkan jika terdapat kandungan deksametason dikategorikan campuran.

Training Set diuji dalam 3 bentuk sediaan sampel yang diperoleh yaitu bentuk rajangan, bentuk serbuk dan bentuk larutan. Hal ini mengikuti dengan bentuk sampel jamu yang diperoleh di pasaran. Kemudian setelah itu Training Set dianalisis menggunakan metode Near Infra Red dan Kemometrik.

\begin{tabular}{llll}
\hline $\begin{array}{c}\text { Deksametason } \\
\text { (gram) }\end{array}$ & $\begin{array}{c}\text { Jamu } \\
\text { Pegal } \\
\text { Linu } \\
\text { (gram) }\end{array}$ & $\begin{array}{c}\text { Konsentrasi } \\
(\%)\end{array}$ & Kategori \\
\hline 0 & 100 & 0 & Murni \\
0,011 & 100 & 1,1 & Campuran \\
0,021 & 100 & 2,1 & Campuran \\
0,032 & 100 & 3,2 & Campuran \\
0,040 & 100 & 4 & Campuran \\
0,051 & 100 & 5,1 & Campuran \\
0,060 & 100 & 6 & Campuran \\
0,073 & 100 & 7,3 & Campuran \\
0,082 & 100 & 8,2 & Campuran \\
0,092 & 100 & 9,2 & Campuran \\
0,1015 & 100 & 10,05 & Campuran \\
0,2040 & 100 & 20,14 & Campuran \\
0,3028 & 100 & 30,18 & Campuran \\
0,4004 & 100 & 40,03 & Campuran \\
0,5014 & 100 & 50,10 & Campuran \\
0,6005 & 100 & 60,00 & Campuran \\
0,7038 & 100 & 70,00 & Campuran \\
0,8022 & 100 & 80,01 & Campuran \\
0,9033 & 100 & 90,93 & Campuran \\
1,0011 & 100 & 100,00 & Campuran \\
\hline
\end{tabular}

(a)

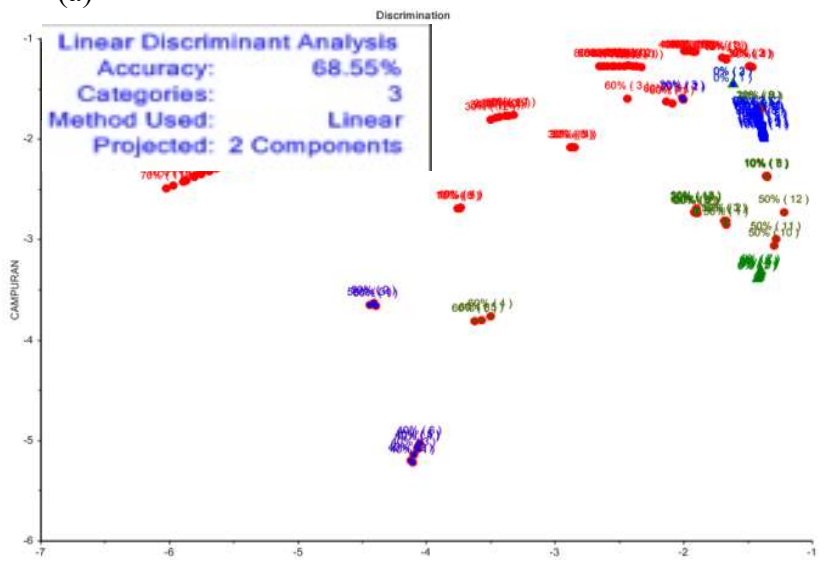

(b) 


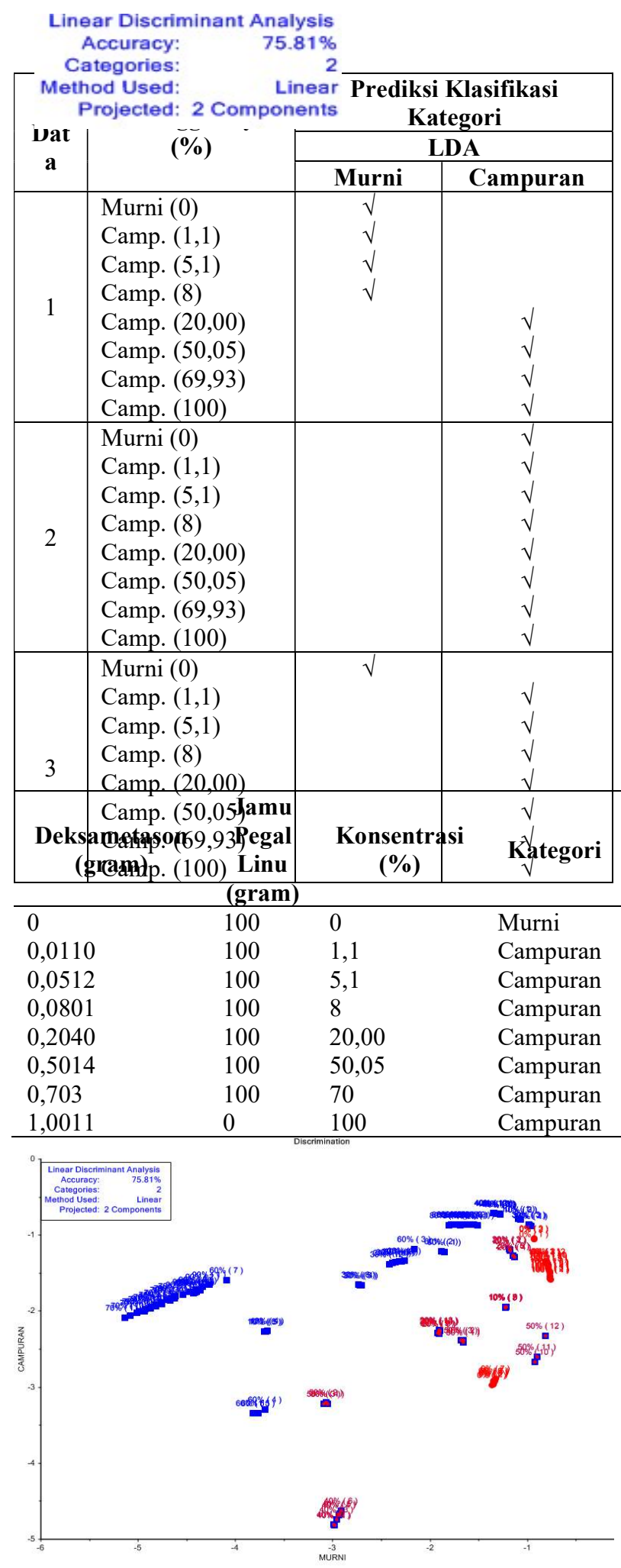

(c)

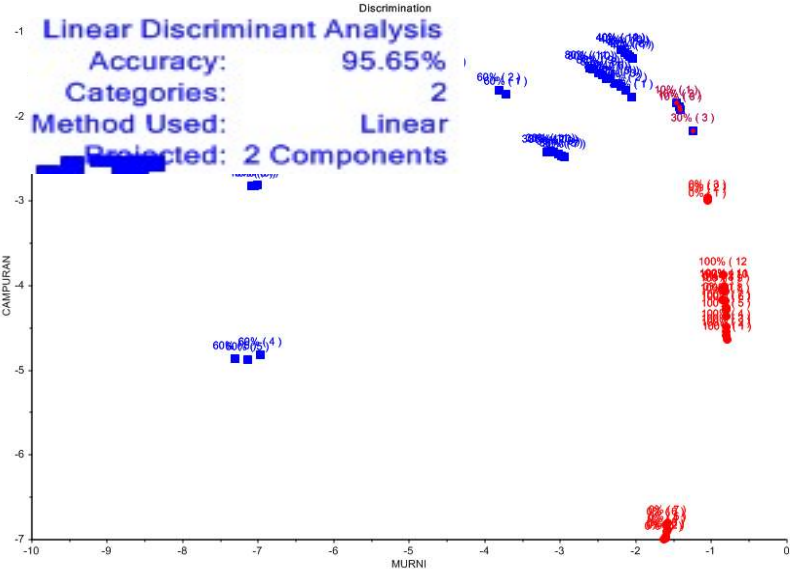

Gambar 1 Set data LDA training set simulasi rajangan (a), serbuk (b) dan larutan (c) jamu pegal + deksametason $0.5 \mathrm{mg}$

Setelah diperoleh hasil analisis, ketiga data tersebut diujikan menggunakan Test set yang berfungsi untuk validasi hasil analisis Training set. Prosedurnya menggunakan Training set yang ditentukan secara acak. Pada analisis ditentukan presentasi Test set adalah sebagai berikut.

Tabel 2. Komposisi dan kategori untuk test set

Dari hasil pengujian simulasi Training Set menggunakan Test set diatas diperoleh

Tabel 3. Hasil klasifikasi model LDA terhadap test set

Kemampuan model dalam membedakan kedua jenis jamu pegal linu dapat dilihat berdasarkan nilai kemampuan pengenalan terhadap sampel dalam training set dan kemampuan prediksi terhadap sampel dalam test set. Model yang ideal adalah model yang memiliki nilai kemampuan pengenalan dan prediksi sebesar $100 \%{ }^{5}$

Tabel 4. Perbandingan nilai kemampuan pengenalan dan prediksi model

\begin{tabular}{ccc}
\hline Set & \multicolumn{2}{c}{ LDA } \\
\cline { 2 - 3 } Data & \% pengenalan & \% Prediksi \\
\hline 1 & 68,55 & 50 \\
2 & 75,81 & 87.5 \\
3 & 95.65 & 100 \\
\hline
\end{tabular}

$\%$ pengenalan: kemampuan pengenalan dalam training set

$\%$ prediksi: kemampuan prediksi dalam test set

Berdasarkan perbandingan diperoleh model 
klasifikasi kemometrik yang terbaik untuk jamu pegal linu murni dan jamu pegal linu campuran adalah model LDA terhadap spektrum IR pada training set bentuk larutan (set data 3) dimana nilai kemampuan pengenalan dan prediksinya masing-masing sebesar 95,65\% dan $100 \%$. Nilai kemampuan sebesar 95,65\% menunjukkan bahwa model LDA tersebut dapat mengklasifikasikan hampir seluruh (20 sampel) training set dengan benar sedangkan nilai prediksi sebesar 100\% menunjukkan bahwa model LDA tersebut dapat memprediksi semua (delapan sampel) test set dengan benar.

Sebelum melakukan sampling, terlebih dahulu dilakukan survei dan pengumpulan data merek jamu pegal linu yang beredar di toko obat dan jamu di wilayah kerja Dinas Kesehatan Kabupaten Jember, utamanya adalah toko obat yang teregister di Dinas Kesehatan Kabupaten Jember. Pengumpulan data sampel diperoleh dengan melakukan sampling terhadap jamu pegal linu melalui observasi.

Setelah dilakukan pengumpulan data kemudian dilakukan analisa berdasarkan data yang diperoleh menggunakan instrumentasi Near Infra Red dan Kemometri. Selanjutnya berdasarkan data toko obat dan toko jamu, dilakukan survey dengan menelusuri daftar merek jamu pegal linu yang beredar di Kabupaten Jember.

\section{Hasil dan Pembahasan}

Hasil instrumentasi ditampilkan dalam bentuk statistik untuk mendapatkan gambaran dalam bentuk tabulasi frekuensi dengan cara menggunakan seluruh data kemudian diolah secara statistik yang dapat dijelaskan berdasarkan tabel berikut:

Tabel 4. Daftar merek jamu pegal linu yang beredar di Wilayah Kerja Dinas Kesehatan Kabupaten Jember

\begin{tabular}{lll}
\hline $\begin{array}{c}\text { Nama } \\
\text { Obat }\end{array}$ & Expired date & \multicolumn{1}{c}{ Bentuk sediaan } \\
\hline J-A & $04-2021$ & Serbuk, Kapsul \\
J-B & $11-2020$ & Kapsul \\
J-C & $09-2020$ & Racikan Simplisia \\
J-D & $09-2020$ & Kapsul \\
J-E & $05-2020$ & Racikan Simplisia \\
J-F & $10-2020$ & Kapsul \\
J-G & $03-2021$ & Serbuk, kapsul \\
J-H & $03-2020$ & Serbuk, Kapsul \\
J-I & $05-2020$ & Sirup \\
J-J & $06-2020$ & Sirup \\
\end{tabular}

Berdasarkan hasil pendataan merek jamu pegal linu terdapat beberapa merek jamu pegal linu yang sama pada dua tempat atau lebih sehingga sampling dilakukan dengan teknik purposif terhadap tiap kelompok. Semua merek jamu pegal linu digunakan sebagai sampel. Oleh karena itu, sampel jamu pegal linu yang digunakan pada penelitian ini sejumlah sepuluh sampel. Selanjutnya dilakukan analisa hasil Pengujian Near Infra Red dan Kemometrik terhadap Adanya Kandungan Bahan Kimia Obat Deksametasone pada Jamu Pegal Linu di Jember

Pada kedua metode ini ditemukan perbedaan hasil analisis, dimana pada metode kemometrik terdapat $2 \%$ kandungan deksametason pada jamu merk J-C Pada pengujian menggunakan metode Near Infra Red diperoleh hasil negatif deksametason pada semua sampel jamu. Metode Near Infra Red merupakan metode kualitatif dimana metode ini melakukan analisa berdasarkan ada atau tidaknya kandungan deksametason pada sampel jamu pegal linu yang diperoleh. Metode ini memiliki kekurangan pada deteksi dalam konsentrasi yang rendah, karena tidak dapat terdeteksi berdasarkan prinsip dari Limit of Detection dari metode spektroskopi Infra merah, dimana Near Infra Red masuk dalam kategori spektroskopi tersebut.

Sedangkan pada metode Kemometrik, dimana secara bahasa adalah meng-angka-kan senyawa kimia, adalah suatu metode kuantitatif, dimana metode ini dapat digunakan untuk analisis jumlah senyawa dalam sediaan sampel. Metode ini bisa lebih mendalam, dikarenakan sangat dimungkinkan terdapat senyawa dalam jumlah kecil yang tidak dapat terdeteksi (Limit of Detection), sehingga senyawa tersebut dapat dihitung dan teridentifikasi.

Berdasarkan hasil analisa diketahui bahwa pada pengujian menggunakan metode Near Infra Red tidak ditemukan adanya kandungan bahan kimia obat deksametason dalam jamu sedangkan pada pengujian menggunakan metode kemometrik ditemukan adanya sampel jamu mengandung bahan kimia obat deksametasone hal ini mengindikasikan bahwa sensitifitas pengujian menggunakan metode kemometrik lebih baik dibandingkan dengan menggunakan metode Near Infra Red.

Menurut Gad, metode Near Infra Red adalah metode dimana dilakukan analisa kualitatif terhadap kandungan suatu senyawa di dalam sampel. Sedangkan metode kemometrik adalah metode analisis dimana dilakukan perhitungan kuantitasi berdasarkan analisa kualitatif pada metode sebelumnya sehingga metode kemometrik akan menentukan presentase dari kandungan senyawa dalam sampel meskipun senyawa tersebut tidak terdeteksi. ${ }^{4}$

Sampel simulasi dibentuk dari rajangan simplisia kering langsung dilakukan analisis menggunakan spektroskopi Near Infra Red dan Kemometrik. Setelah itu, simplisia dikeringkan dalam oven dengan suhu $55^{\circ} \mathrm{C}$ dalam waktu 2 jam, kemudian digerus menggunakan mortir dan stamper, sehingga menjadi sediaan serbuk dan langsung dilakukan analisis menggunakan spektroskopi Near Infra Red dan Kemometrik. Kemudian setelah itu 
untuk sediaan larutan, serbuk jamu diseduh menggunakan air panas, kemudian langsung dilakukan analisis menggunakan spektroskopi Near Infra Red dan Kemometrik.

Dilakukan pengeringan menggunakan oven dengan suhu $55^{\circ} \mathrm{C}$ dalam waktu 2 jam bertujuan untuk menghilangkan senyawa pengganggu yang mungkin terdapat dalam kandungan air sampel. Air merupakan media pertumbuhan bakteri yang baik, sehingga dengan menghilangkan kandungan air dalam sampel dapat meminimalisir adanya bakteri dalam sampel. Pun demikian dengan penyeduhan sampel dengan air panas sebelum dilakukan analisis, selain bertujuan untuk menyerupakan jamu pegal linu yang dikonsumsi, juga untuk mengurangi adanya bakteri dalam sampel.

Pada hasil pengujian simulasi training set, diperoleh nilai regresi dan persentase analisis diskriminan yang berbeda. Nilai dan persentase pada set data training set bentuk larutan lebih tinggi daripada set data training set bentuk simplisia dan serbuk. Hal ini dapat disebabkan pada prinsip kerja Near infra red, yaitu timbulnya spektra spesifik akibat vibrasi molekul pada interaksi antara sampel dengan infra red, terdapat perbedaan interaksi yang terjadi. ${ }^{6}$

Pada sampel padat, interaksi yang terjadi antara infra red dan sampel akan dibaurkan. Hal ini dikarenakan rapatnya jarak antar molekul penyusun sampel sehingga infra red tidak dapat mengidentifikasikan senyawa dalam sampel secara spesifik. Sedangkan pada sampel larutan interaksi dengan infra red lebih maksimal, karena molekul penyusun berada dalam pembawa, sehingga pada percobaan model menggunakan training set, hasil terbaik adalah model dalam bentuk larutan. Sehingga apapun bentuk sampel yang diperoleh akan diolah menjadi larutan sebelum dilakukan analisis menggunakan instrumentasi. ${ }^{7}$

Hal ini juga mempengaruhi perbedaan nilai regresi dan persentase diskriminan yang dihasilkan dari ketiga set data. Set data larutan jamu memiliki nilai regresi dan presentase diskriminan paling tinggi dari set data simplisia dan set data serbuk jam, dikarenakan hasil interaksi antara infra merah dan sampel yang lebih maksimal, sehingga nilai regresi, yang menunjukkan nilai hubungan antara konsentrasi dan absorbansi, akan semakin baik.

Metode Near Infra Red dan kemometrik yang dilakukan sampling terhadap 10 merk jamu pegal linu yang beredar di toko obat dan toko jamu yang berada di wilayah kerja Dinas Kesehatan Kabupaten Jember menunjukkan bahwa sebagian besar jamu tidak memiliki kandungan bahan kimia obat deksametasone namun 1 sampel terindikasi adanya bahan kimia obat deksametason dengan konsentrasi sebanyak $2 \%$.

Penelitian ini dilakukan karena jumlah masyarakat yang mengkonsumsi jamu pegal linu berdasarkan data dari Dinas Kesehatan Kota Jember semakin banyak, berbanding lurus dengan jamu pegal linu ditarik dari peredaran karena mengandung bahan kimia obat, dimana salah satunya adalah Deksametason. Kesalahan fatal yang dilakukan oleh produsen jamu adalah menggunakan deksametasone sebagai bahan campuran dalam pembuatan jamu pegal linu. deksametasone secara sadar ditambahkan ke dalam racikan atau sediaan jamu tradisional yang menjadikan jamu tersebut semakin berkhasiat secara instan dalam upaya memberikan efek menghilangkan pegal linu. Produsen jamu biasanya memilih bahan deksametason karena deksametason sendiri merupakan golongan obat kortikosteroid yang memiliki harga relatif murah dibandingkan kortikosteroid lain, namun apabila dikonsumsi dalam dosis yang berlebihan dan dalam jangka waktu yang panjang dapat menimbulkan efek samping tidak diharapkan seperti moonface atau gangguan hormon.

Dosis deksametason, berdasarkan Stockley, harus memenuhi kadar yang telah ditetapkan dalam literatur. Berdasarkan hasil penelitian yang dilakukan, diperoleh kadar deksametasone dalam jamu pegal linu yang beredar di Kabupaten Jember tidak tinggi jika dibandingkan dengan deksametasone dalam bentuk obat golongan steroid. Dosis deksametasone yang secara umum digunakan pada penggunaan oral adalah sekitar 0,5 - $1 \mathrm{mg} /$ hari; anak $5-75 \mathrm{mcg} / \mathrm{kg}$ bb/hari. Injeksi yang diberikan secara intramuskular atau intravena infus yang digunakan sebagai deksametason fosfat, dosis awal yang diberikan adalah 0,5 - $12 \mathrm{mg}$; dosis inisiasi untuk anak 100 - $200 \mathrm{mcg} / \mathrm{kg}$ bb/hari. Timbulnya edema serebral yang berhubungan dengan kehamilan, maka terapi diberikan melalui injeksi intravena, diberikan dosis awal $10 \mathrm{mg}$, kemudian dilakukan tapering dose inisiasi dari 4 mg melalui injeksi intramuskular tiap 6 jam selama 2-4 hari kemudian secara bertahap dikurangi dan dihentikan setelah 5-7 hari. Pengobatan pendukung untuk terapi bakteri meningitis secara injeksi intravena $10 \mathrm{mg}$ tiap 6 jam selama 4 hari; anak $150 \mathrm{mcg} / \mathrm{kg}$ bb tiap 6 jam selama 4 hari. Deksametason $1 \mathrm{mg}$ sebanding dengan deksametason fosfat $1,5 \mathrm{mg}$ sebanding dengan deksametason natrium fosfat $1,8 \mathrm{mg}$. Pemberian oral pada anak-anak: $8 \mu \mathrm{g} / \mathrm{kg}-100 \mu \mathrm{g} / \mathrm{kg}$ sekali, $30 \mu \mathrm{g} / \mathrm{kg}$ $400 \mu \mathrm{g} / \mathrm{kg}$ sehari. Pemberian oral pada dewasa: $1 \mathrm{mg}-3$ mg sehari. Namun walaupun penggunaannya masih berada dibawah ambang batas, deksametasone tidak diperbolehkan terdapat dalam kandungan jamu sesuai dengan ketentuan dalam Permenkes RI Nomor 007 Tahun 2012 bahwasanya jamu atau obat tradisional tidak diperkenankan memiliki kandungan bahan kimia sintetis atau hasil isolasi yang berkhasiat sebagai obat.

Dibandingkan dengan metode sebelumnya yang pernah digunakan untuk penelitian serupa, metode Near Infra Red Dan Kemometri memiliki beberapa keunggulan, antaralain biaya yang dibutuhkan dalam penelitian tidak tinggi, mudah dalam pelaksanaan instrumentasi sehingga peneliti tidak menemukan kesulitan dalam melakukan analisis, serta hasil yang didapat bisa langsung dilakukan deskripsi sehingga peneliti dapat memperoleh hasil penelitian yang diinginkan.

Pada masa mendatang, sangat mungkin ditemukan metode baru yang dapat digunakan untuk mengidentifikasi senyawa bahan kimia sintetis pada sampel jamu pegal linu yang lebih murah dan lebih 
mudah dalam melakukan pengoperasian. Diharapkan juga dikembangkan suatu metode baru yang dapat digunakan untuk mengidentifikasi satu atau lebih senyawa bahan kimia sintetis dalam satu atau lebih sampel jamu pegal linu atau jamu yang lain, sehingga masyarakat bisa memperoleh obat tradisional yang aman dan bermanfaat.

\section{Kesimpulan}

Kesimpulan dari penelitian yamg kami lakukan adalah dengan penerapan penggunaan metode Near Infra Red - Kemometrik ditemukan adanya kandungan bahan kimia sintetis deksametason pada 1 sampel jamu pegal linu dengan konsentrasi sebesar $2 \%$ di sampel toko obat di Kabupaten Jember. Jumlah tersebut dapat menyebabkan efek samping obat yang tidak diharapkan apabila dikonsumsi secara terus menerus.

\section{Ucapan Terima Kasih}

Ucapan terimakasih senantiasa kami haturkan kepada Orang tua peneliti, dosen pembimbing dan penguji dari peneliti, serta kepada instansi yang telah banyak memberikan support dan bantuan kepada peneliti sehingga penelitian dapat berjalan dengan lancar.

\section{Referensi}

[1] Kementerian Perdagangan. 2014. Obat Herbal Tradisional. Warta Ekspor edisi 005/9/2014 September. Jakarta: Direktorat Jenderal Pengembangan Ekspor Nasional Kementerian Perdagangan

[2] Badan Pengawas Obat dan Makanan. 2013. Deksametasone. Sentra Keracunan Nasional. http://ik.pom.go.id diakses 22 Mei 2019 pukul 14.146

[3] Schwanninger.,et al. 2011. A Review Of Bdan Assigments in Near Infrared Spectra of Wood dan Wood Component. Journal Of Near Ifrared Spectroscopy Vol 19 No 287-308

[4] Gad.,et al. 2012. Aplication of Chemometrics in Authentication Of Herbal Medicine. Journal Of Phytochemical Analysis Vol 24 No 1

[5] Miller dan Miller. 2010. Statistics and Chemometrics for Analytical Chemistry. Sixth Edition. Harlow: Pearson Education

[6] Mistry. 2009. A Handbook of Spectroscopic Data Chaemestry. Jaipur: Oxford Book Company

[7] Stuart. 2004. Infrared Spectroscopy: Fundamental and Applications. Philadelphia: Saunders College Publishing. 